\title{
THE IMPACT OF AEROBIC EXERCISE ON MORPHOLOGICAL CHARACTERISTICS AND AGILITY IN CHILDREN
}

\section{AUTHORS}

Stanić $Đ .^{1}$, Pržulj D. ${ }^{1}$, Božović A. ${ }^{2}$

${ }_{1}^{1}$ University of Eastern Sarajevo, Faculty of Physical Education and Sports, Eastern Sarajevo, Republic of Serbska

${ }^{2}$ Medical Faculty, University of Priština, Kosovska Mitrovica, Serbia

\section{SUMMARY}

We examined the impact of aerobic exercise on morphological characteristics and agility in elementary school children. Anthropometric characteristics of the subjects were as follows: longitudinal skeletal dimension (body height, as well as the lengths of upper and lower extremities), circular skeletal dimension and body mass (mean circumference of the chest, the circumference of the thigh of an stretched leg, maximum circumference of the calf, body mass) and subcutaneous fat (skin thickness of the abdomen, thigh and calf). The agility was estimated by the envelope test, side steps and a eight with bending. For statistical analysis we employed the basic methods of descriptive statistics, while the discriminatory power of measurements was estimated by calculation of skewness and kurtosis of the data. Canonical correlation analysis was applied to explain the structure of the relationships between the two sets of data. The results of the analysis on this sample suggest that there is a strong linear relationship between morphological characteristics and agility at a multivariate level.

Keywords: Aerobic exercise, Agility, Morphological characteristics, Canonical analysis.

\section{INTRODUCTION}

It is well known that physical education in elementary schools has been facing, for a long time, a number of problems that adversely affect its efficiency. Physical education classes in secondary schools, according to some researchers [1,2], predominantly insist on the informatic component of the performance (learning motor skills), therefore, their exercises are usually not effective enough to develop the skills and characteristics which are the basic requirements for the changes of the quantitative and qualitative dimensions of students' anthropological status. Since physical education is also inadequately covered by the number of classes per week (two classes), the teaching is achieved through the low energy component, which is a major problem in achieving the goals and objectives of the physical education program [3].

Literature data show that the identification of the skills and characteristics in children and adolescents based mainly on the genetic factor, with the addition of the external factors, does not contribute to the detection of the scientifically based interrelationships, or the so-called neurophysiological relationships, and the influence of the external factors [3-6]. Therefore, in recent years there has been an increased interest in the examining the interactions between the dimensions of anthropological characteristics and their association with the success achieved in sport activities that are offered by the physical education programs, by using the multivariate processing methods of students' results.

An increasing number of studies indicate the validity of the previously formulated integral development theory, particularly in relation to determining the correlation between motor skills and other subsystems of the psychosomatic status [5,7-10]. Some researchers have repeatedly found a positive correlation between anthropometric measures of morphological characteristics, motor and functional skills, on the one hand, and the results of athletic disciplines that are implemented in the regular physical education class program, on the other $[4,6,11-13]$. Nevertheless, little research has been done involving the elementary school students using the modern methods and methodology in order for the obtained results to be accepted as applicative value in physical education and the implementation of program tasks dominated by agility and explosive strength [6]. For these reasons, the present study examined the influence of morphological characteristics and motor skills on the results achieved in agility and explosive strength in the elementary school students, which would result in better results in physical education. Since there is a possibility of a significant mutual interaction between morphological characteristics and agility, the aim of this study is to determine the relationship between the morphological characteristics and the resulting efficiency in the agility of the students in the final year of elementary school, in aerobic exercise. 


\section{MATHERIAL AND METHODS}

\section{SUBJECTS}

This pilot study involved the students of both gender in the final year of elementary school in Kosovska Mitrovica, who were included in the regular physical education activities and aerobic exercise. There were previously defined conditions that all the subjects had to meet before the study was conducted, namely: during the measurements and tests all the subjects needed to be clinically healthy and without any significant psychological and physical abnormalities, and they voluntarily agreed to participate in the study.

\section{ANTHROPOMETRIC MEASUREMENTS AND AGILITY TESTS}

Anthropometric measurements included the following variables: longitudinal dimensionality of the skeleton is defined depending on the height of the body in centimeters (AVIS), the length of the arm in centimeters (ADRK) and the length of the leg in centimeters (ADUN). The circular dimensionality of the skeleton and the body mass were defined based on the mean circumference of the chest in centimeters (AOGK), the circumference of the thigh of the stretched leg in centimeters (AOBU), the maximum circumference of the calf in centimeters (AOPK) and body mass in kilograms (AMAS). The subcutaneous fat tissue was defined by the abdominal skinfold thickness in millimeters (AKNN), thigh skinfold thickness in millimeters (ACNB) and lower leg skinfold thickness in millimeters (AKNP). The proposed model of the anthropometric measures sample for the evaluation of morphological characteristics was applied according to the instructions of Kurelić and associates [3].

The agility of the subjects was evaluated using the following tests: 1 . the envelope test (MKOT), side steps (MKUS) and eight with bending (MOSS). When selecting the measuring instruments their reliability, objectivity and validity were taken into account. The variables for this study were selected to evaluate the morphological and motor dimensions established as a predictor system, as well as the agility, established as a criterion system.

\section{STATISTICAL METHODS}

The obtained data were shown as: the mean value (MEAN), the minimum value (MIN), the maximum value (MAX), the standard deviation (SD), the range (RANGE), and the standard error of the mean value (ERROR). The measurement discrimination was assessed based on skewness and kurtosis of the data distribution curve [5]. The inter-correlation matrix of anthropometric measures, motor skills and short track speed testing were also applied. Canonical correlation analysis was used to explain the structure of relations between the two sets of variables. The canonical correlation value was calculated (Can. R) and then the canonical root (coefficient) of determination (Can. R2), which is the percentage of common variance of the studied area. The significance of the canonical correlation coefficient was tested via Bartlett chi-square test.

\section{RESULTS}

This study included 112 primary school students of both gender, with the average years of age $14.0 \pm 0.5$. The obtained data of morphological characteristics of the subjects are shown in Table 1. Our results (Table 1) show that none of the anthropometric measures of the subjects' morphological characteristics differed significantly from the normal distribution. In addition, the intervals of the minimum and maximum values of the results contained at least five standard deviations, indicating substantial scattering, i.e. the sensitivity of anthropometric measures.

The results of the subjects' agility testing are shown in Table 2. The results show that there is no significant deviation from the normal Gaussian distribution. At the intervals of the minimum and maximum values there were at least five standard deviations, which indicate a significant sensitivity of the agility tests.

Table 1. The main morphological characteristics in the subjects $(n=112)$

\begin{tabular}{|c|c|c|c|c|}
\hline Variable & Mean \pm SD & Range & Skewness & Kurtosis \\
\hline Body height $(\mathrm{cm})$ & $167.3 \pm 3.2$ & $162.0-186.0$ & 0.178 & 0.898 \\
\hline Arm length $(\mathrm{cm})$ & $72.5 \pm 1.6$ & $68.0-88.0$ & 0.342 & -1.187 \\
\hline Leg length $(\mathrm{cm})$ & $96.7 \pm 5.5$ & $89.0-106.0$ & 0.511 & 0.571 \\
\hline The mean circumference of the & $81.6 \pm 5$ & $76.0=92.0$ & 0.9 & 1.424 \\
\hline The circumference of the stretch & $44.8 \pm 8.8$ & $41.0^{0}-49.0^{-}$ & $=0.057$ & 0.439 \\
\hline The maximum circumference of & $32.2 \pm 2.9$ & $29.0-3$ & - n & 771 \\
\hline Body weight $(\mathrm{kg})$ & 56. & $52.0-76.0$ & 0.4 & \\
\hline Skinfold thickness ( $\mathrm{n}$ & & & & \\
\hline - abdomen & $10.6 \pm 13.5$ & $6.0-14.0$ & -0.160 & 0.333 \\
\hline - thigh & $12.7 \pm 6.3$ & $9.0-17.0$ & 0.034 & -0.557 \\
\hline - shin & $9.5 \pm 4.2$ & $7.0-12.0$ & -0.200 & 0.321 \\
\hline
\end{tabular}

The table shows the arithmetic mean value (Mean), the standard deviation (SD) as well as the range of the minimum and maximum values, skewness and kurtosis.

Table 2. The main statistical parameters for assessing agility in subjects ( $n=112$ )

\begin{tabular}{|c|c|c|c|c|}
\hline TEST & Mean \pm SD & Range & Skewness & Kurtosis \\
\hline The envelope test & $18.72 \pm 4.21$ & $15.00-19.00$ & -0.196 & 0.242 \\
\hline The steps aside & $11.84 \pm 3.00$ & $9.00-15.00$ & $0 . \overline{30} \overline{6}$ & -0.600 \\
\hline Eight with bending & $14.36 \pm 1.97$ & $11.00-18.00$ & $0 . \overline{259}$ & $-0.42 \overline{3}$ \\
\hline
\end{tabular}

The table shows the arithmetic mean value (Mean), the standard deviation (SD) as well as the range of the minimum and maximum values, skewness and kurtosis. 
Table 3. The correlation matrix of morphological characteristics in subjects

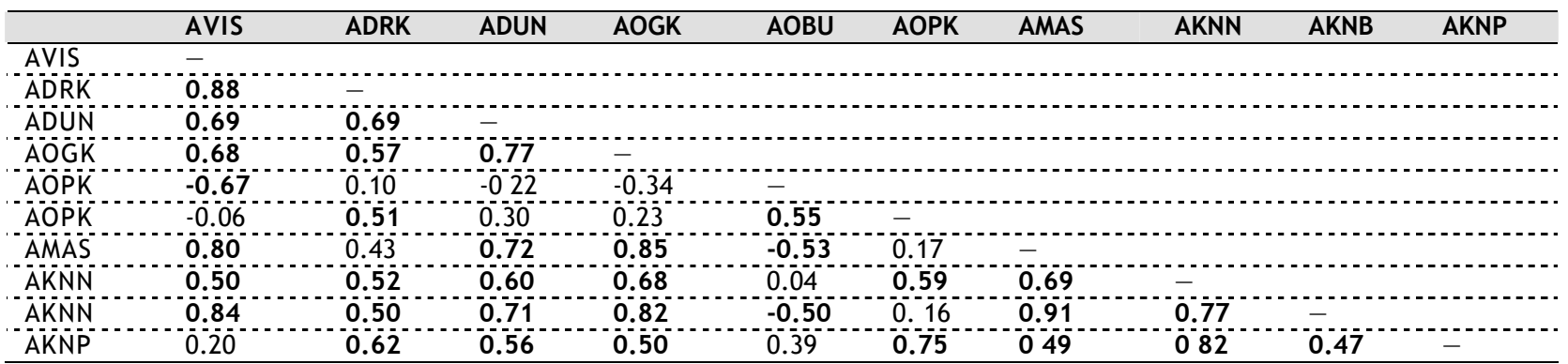

Abbreviations used are as follows: AVIS (body height in $\mathrm{cm}$ ), ADRK (Arm length in $\mathrm{cm}$ ), ADUN (leg length in $\mathrm{cm}$ ), AOGK (Middle circumference of the chest in $\mathrm{cm}$ ), AOBU (Thigh circumference of the stretched leg in $\mathrm{cm}$ ), AOPK (Maximum circumference of the lower leg in $\mathrm{cm}$ ), AMAS (body mass in $\mathrm{kg}$ ), AKNN (abdominal skinfold thickness in mm), AKNB (thigh skinfold thickness), AKNP (lower leg skinfold thickness in $\mathrm{mm}$ ). Results in bold represent the statistically significant linear correlation coefficients $(p<0.05)$

Table 4. The correlation matrix of morphological characteristics in subjects

\begin{tabular}{|c|c|c|c|c|c|}
\hline & $\mathbf{R}$ & $\mathbf{R}^{2}$ & Chi-sqr. & df & $P$ \\
\hline 0 & 0.67 & 0.44 & 68.60 & 90 & 0.000 \\
\hline$\overline{1}$ & 0.35 & 0.12 & $23.98^{-}$ & 41 & 0.264 \\
\hline$\overline{2}^{-}$ & 0.12 & 0.01 & 20.56 & 24 & 0.389 \\
\hline
\end{tabular}

The table shows the canonical correlation coefficient $(R)$, the coefficient of determination (R2), the chi-square test (Chi-sqr.), the degree of freedom (DF.) and significance (P)

Table 5. The canonical factors of criterion variables

\begin{tabular}{c} 
TEST \\
\hline The envelope test \\
SÉteps aside
\end{tabular}

The agility canonical factors (Table 5 ) indicate the existence of a one-dimensional structure of the space. The factor of the agility success is best defined by the envelope test (MKOT - 0.58).

The inter-correlation matrix of morphological characteristics in subjects is shown in Table 3. As shown by our results, the highest correlation coefficient $(r=0.91)$ was found between thigh skinfold anthropometric values (ACNB) and body mass (AMAS).

The next step was the examining the relationship between the various parameters of agility. There was a statistically significant correlation between the eight with bending and the envelope tests $(r=-0.49, p<0.05)$, between the steps aside and eight with bending tests $(r=-$ $0.40, p<0.05$ ) and between the envelope and the eight with bending tests $(r=-0.38, p<0.05)$.

The results of the canonical correlation analysis of morphological characteristics and success in agility are shown in Table 4. The results of this analysis show that the relations between the predictor system, which consists of the variables for the evaluation of morphological characteristics, and the criterion system, which consists of the variables for assessing agility, led to a statistically significant pair of canonical factors.

The canonical factor (Table 4) explains the integration level of a set of predictor variables with the criteria $(R=67)$, as well as their shared variance $(R 2=.44)$, resulting in the influence of the morphological characteristics on the success in agility being explained by the coefficient of determination of $44 \%$. The probability of error in rejecting the hypothesis of whether the function is significant or not, was determined between the predictors and criteria $(\mathrm{P}=.000)$ at the level of $99 \%$. Based on the structure of canonical factors it can be concluded that the primary factors of morphological characteristics did not equally participate in the formation of the canonical factors structure, which means that this canonical dimension is slightly different from the general factor. It may be noted that a large number of factors affect the efficient generation of the agility variables, although their influence is different. Most effective factors are the circumference of the thigh (AOBU -0.55) and the thigh skinfold (AKNB -0.41).

\section{DISCUSSION}

The results presented in this study show that there is, at the multivariate level, a correlation between the morphological characteristics and the agility in children involved in the aerobic exercise testing. The skewness value of the morphological characteristics in our subjects indicates that none of the measures show a significant difference between the obtained results and the normal distribution, since the values do not exceed 1.00 in any of the anthropometric measures. Our results also show that the subjects exhibit kurtosis values below the normal distribution value of 2.75 , which makes the distribution platykurtic or lengthy. The results of the anthropometric measures do not differ from the results of similar tastings we conducted on this group of subjects, which consequently enabled the application of the multivariate methods of data analysis in this study. This allows for the generalization of the results obtained from this population, from which the sample of the subjects was isolated.

These results imply that the individuals' morphological characteristics may be a predisposing factor of 
their future performance as athletes. Regardless of its role in sport training, aerobic exercise can have a positive effect on many aspects of life and work in non-athletes. Thus, the recent research shows that aerobic exercise enhances the learning and helps memorizing the covered material in school age children $[13,14]$. Based on the analysis of the cross-correlation matrix of morphological variables and the variables of the success in agility in these subjects, it can be concluded that there are different levels of interdependence. Taking into account all displayed measurements and their correlation with the agility tests, our results suggest that in children finishing elementary school the success in agility can significantly be contributed to the anthropometric measurements of the circumference of the thigh (AOBU) and thigh skinfold (AKNB).

The results of the previous studies show that the teaching practices of the regular and extra physical education classes are lacking in the necessary scientifically based plans and programs for immediate implementation of the regular and extra physical education teaching programs, which is especially present in certain specific motor skills of agility and explosive strength $[15,16,17]$. The results of the research done by some authors on the high school athletes showed a positive influence and relationship between the morphological characteristics dimensions and the motor skills on the one hand, and the resulting efficiency in agility and explosive strength, on the other $[3,10,13]$.

\section{CONCLUSION}

Based on acquired research data, we can conclude that dental injuries in examined children are relatively frequent in relation to the number and age of the examined children, as well as that they are most frequent at the ages of 3 and 4, with uncomplicated enamel and dentine injuries and fractures of the enamel of the crown being the most frequent. These injuries most often occur when falling or by an impact with a hard object, inside the house or in the yard. Traumatic dental injuries belong to a specific group of injuries that cannot heal, which causes permanent consequences. Although modern treatment methods can quite successfully take care of teeth injured by trauma, replacing the lost part of the crown or the whole tooth is a very complex therapeutic procedure. Regardless of the success of these recuperations, the same level of tooth function as before the injury can never be achieved. For all the reasons stated, the significance of prevention measures is clear. These measures can be applied with a lot of success, regardless of many causes that lead to dental injuries. This sort of research enables us to understand the complexity and aetiology of dental injuries better and successfully apply preventive strategies to reduce the increase of trauma prevalence and incidence; therefore it is necessary to conduct more epidemiological studies on representing populations.

\section{REFERENCES}

1. Shephard, R.J. Effectiveness of training programs for prepubescent children. Sports Meicine 1992; 13: 194-213.

2. Olds T, Tomkinson G, Leger L, Cazorla G. Worldwide variation in the performance of children and adolescents: An analysis of 109 studies of the 20-m shuttle run test in 37 countries. J Sports Sci 2006; 24:1025-1038.

3. Tremblay A, Simoneau JA, Bouchard C. Impact of exercise intensity on body fitness and skeletal muscle metabolism. Metabolism 1994; 43(7):814-818.

4. Bala G. (1981). Struktura i razvoj morfoloških dimenzija dece SAP Vojvodine. Novi Sad; Fakultet fizičke kulture Univerziteta u Novom Sadu (OOUR Institut fizičke kulture.

5. Coledam DHC, Paludo AC, de Oliveira AR, Dos-Santos JW. Dynamic exercise versus tag game warm up: the acute effect on agility and vertical jump in children. J Human Sport Exer 2012; 7:243-253

6. Coledam DHC, Paludo AC, de Oliveira AR, Dos-Santos JW. Dynamic exercise versus tag game warm up: the acute effect on agility and vertical jump in children. J Human Sport Exer 2012; 7:243-253

7. Ostojić D, Pejović T, Ostojić S. Assessment of physical fitness in children and adolescents. Facta Univ 2013; 11:135-145.

8. Egan B, Zierath JR. Exercise metabolism and the molecular regulation of skeletal muscle adaptation. Cell Metabolism 2012; 17:162-184.

9. Grassi GP, Turci M, Sforza C. Aerobic fitness and somatic growth in adolescent: a cross sectional investigation in a high school context. J Sports Med Phys Fitness 2006; 46(3):412-418.

10. Amiri-Khorasani M, Sahebozamani M, Tabrizi KG, Yosuf AB. Acute effect of different stretching methods on Illinois agility test in soccer players. J Strength Cond Res 2011; 24:2698-2704. 
11. Mandarić S, Sibinović A, Stojiljković S. Effects of a high-low program on the morphological features, functional and motor abilities of female elementary school eight graders. Facta Univers 2011; 9(3): 307-319.

12. Najšteter, D. (1991). Metode i organizacioni oblici rada. U: Teorija i metodika sportskog treninga, Sarajevo, 39-48.

13. Pržulj, D. (2004). Topološke karakteristike proporcionalnosti tjelesne grade dječaka uzrasta 10 godina, II simpozijum antropologa Republike Srpske sa međunarodnim učešćem. Zbornik sažetaka (35-36). Jahorina: Društvo antropologa Republike Srpske.

14. Monti JM, Hillman CH, Cohen NJ. Aerobic fitness enhances relational memory in preadolescent children: The FITKids randomized control trial. Hippocampus 2012; 22:1876-1882.

15. Truter L, Peinaar AE, Toit D. The relationship of overweight and obesity to the motor performance of children living in South Africa. S Afr Fam Pract 2012; 54:429-435.

16. Raine LB, Lee HK, Saliba BL, Chaddock-Heyman L, Hillman CH, et al. The influence of childhood aerobic fitness on learning and memory. PLoSONE 2013; 8(9):e72666.doi:10.1371/journal.pone.0072666.

17. Sharma R, Nigam AK. A study of body mass index in relation to motor fitness components of school going children involved in physical activities. J Exer Sci Physiother 2011; 7:29-33.

\section{SRPSKI}

\section{UTICAJ AEROBNOG VEŽBANJA NA MORFOLOŠKE KARAKTERISTIKE I AGILNOST DECE}

\section{Stanić $D .{ }^{1}$, Pržulj D. ${ }^{1}$, Božović A. ${ }^{2}$}

${ }^{1}$ Fakultet fizičkog vaspitanja i sporta, Univerzitet u Istočnom Sarajevu, Istočno Sarajevo, Republika Srpska

${ }^{2}$ Medicinski Fakultet Univerziteta u Prištini, Kosovska Mitrovica, Srbija

\section{SAŽETAK}

Deca su sve češče izložena povredama među kojima su povrede zuba često zastupljene. Zastupljenost traumatskih povreda zuba varira u odnosu na uzrast dece, zbog čega se pojedine starosne grupe smatraju podložnijim za njihov nastanak. Cilj ovog rada je bio da se utvrdi i analizira zastupljenost i distribucija traumatskih povreda zuba, vrsta povreda zuba, kao i mesto i način nastanka povreda. Istraživanjem je obuhvačeno 404 dece (204 dečaka i 200 devojčica) uzrasta 3 do 6 godina, koja su metodom slučajnog uzorka odabrani iz obdaništa na području severnog dela Kosovske Mitrovice. Povrede zuba su klasifikovane prema klasifikaciji Andreasena baziranoj na sistemu koji je prihvatila Svetska zdravstvena organizacija. Rezultati istraživanja su pokazali da su povrede zuba zastupljene kod $14,11 \%$ ispitivane dece i da su najzastupljenije u uzrastu 3 (21,25\% ) i 4 godine (15,95\%). Zastupljenost povreda zuba se razlikovala samo između grupa dece uzrasta 3 i 6 godina (hi-kvadrat test $=3,49 ; p=0,06$ ). Od ukupnog broja pregledane dece $15,69 \%$ dečaka i 12,50 devojčica je imalo povredu zuba. Različite vrste povreda zuba su bile slično distribuirane u različitim uzrastima dece, pri čemu su najzastupljeniji nekomplikovani prelom gleđi i dentina $(28,07 \%)$, zatim naprsnuća i prelom gleđi krunice zuba (24,56\%). Kod 52,63\% dece pad je bio uzrok povrede zuba, dok je udarac u tvrd predmet uzrok povrede zuba kod $29,82 \%$ dece. U uzrastima dece 4,5 i 6 godina, povrede nastale prilikom pada ili udaraca u tvrde predmete su zastupljene sa malom razlikom. Većina povreda zuba u dece se dogodila u dvorištu $(35,09 \%)$ ili u kući $(33,33 \%)$. Na osnovu dobijenih rezultata istraživanja možemo zaključiti da su povrede zuba u ispitivane dece zastupljene u relativno visokom procentu obzirom na broj i uzrast dece, kao i da su najčešće u uzrastu od 3 godine.

Ključne reči: traumatska povreda zuba, vrste povreda zuba, etiologija povreda. 